\title{
Asian soybean rust in Brazil: past, present, and future
}

\author{
Cláudia Vieira Godoy(1), Claudine Dinali Santos Seixas ${ }^{(1)}$, Rafael Moreira Soares ${ }^{(1)}$, \\ Franscismar Correa Marcelino-Guimarães ${ }^{(1)}$, Maurício Conrado Meyer ${ }^{(1)}$ and Leila Maria Costamilan ${ }^{(2)}$
}

\begin{abstract}
(1)Embrapa Soja, Rodovia Carlos João Strass, s/no, Acesso Orlando Amaral, Distrito de Warta, Caixa Postal 231, CEP 86001-970 Londrina, PR, Brazil. E-mail: claudia.godoy@embrapa.br, claudine.seixas@embrapa.br, rafael.soares@embrapa.br, francismar.marcelino@embrapa.br, mauricio.meyer@embrapa.br (2)Embrapa Trigo, Rodovia BR-285, Km 294, Caixa Postal 3081, CEP 99050-970 Passo Fundo, RS, Brazil. E-mail: leila.costamilan@embrapa.br
\end{abstract}

\begin{abstract}
Asian soybean rust, caused by the fungus Phakopsora pachyrhizi, is the most severe disease of the crop and can cause yield losses of up to $90 \%$. The disease was first reported in Brazil in 2001. Epidemics of the disease are common in the country, where the fungus can survive year-round. Regulatory measures to reduce the inoculum between seasons and avoid late-season soybean have been adopted to manage the disease. Disease control has relied mainly on chemical control, but a lower sensibility of the fungus to fungicides has been reported in Brazil. Major-resistance genes have been mapped and incorporated into the cultivars. With the reduced efficacy of the fungicides, the adoption of integrated measures to control the disease will be important for the sustainability of the crop. This review presents the main changes in the soybean crop system caused by the introduction of the fungus in Brazil, the current management strategies adopted to avoid losses, and the new trends that, together with biotechnological strategies, can improve management in the future.
\end{abstract}

Index terms: Glycine max, Phakopsora pachyrhizi, biotechnology, chemical control, genetic resistance, losses, management.

\section{Ferrugem-asiática da soja no Brasil: passado, presente e futuro}

Resumo - A ferrugem-asiática da soja, causada pelo fungo Phakopsora pachyrhizi, é a doença mais severa da cultura e pode causar perdas de produtividade de até $90 \%$. A doença foi relatada pela primeira vez no Brasil em 2001. Epidemias da doença são comuns no País, onde o fungo pode sobreviver durante todo o ano. Medidas regulatórias para reduzir o inóculo entre safras e evitar a semeadura tardia de soja têm sido adotadas para manejar a doença. O controle da doença tem se baseado principalmente no controle químico, mas uma menor sensibilidade do fungo aos fungicidas tem sido relatada no Brasil. Genes de resistência têm sido mapeados e incorporados às cultivares. Por causa da redução da eficiência dos fungicidas, a adoção de medidas integradas para o controle da doença será importante para a sustentabilidade da cultura. Este artigo de revisão apresenta as principais mudanças no sistema de produção da soja causadas pela introdução do fungo no Brasil, as medidas de controle atualmente usadas para evitar perdas, e as novas tendências que, juntas com estratégias biotecnológicas, podem melhorar o manejo da doença no futuro.

Termos para indexação: Glycine max, Phakopsora pachyrhizi, biotecnologia, controle químico, resistência genética, perdas, manejo.

\section{Introduction}

Brazil harvested 209.5 million tons of grain in $2014 / 2015$ in an area of 58.04 million hectares, and soybean [Glycine max (L.) Merr.] stood out as the main crop sown. The cultivated soybean area has nearly tripled in the last 20 years, from 11.6 million hectares in 1994/1995 to 32.1 million hectares in 2014/2015 (Companhia Nacional de Abastecimento, 2015). One disease that threatens the sustainability of the crop and represents a breakthrough in the history of soybean in Brazil is Asian soybean rust (ASR), caused by the fungus Phakopsora pachyrhizi. This fungus was first identified in Japan as Uredo sojae in 1902, and it was detected throughout tropical and subtropical Asia and Oceania in the early $20^{\text {th }}$ century (Bromfield, 1984). The disease was first reported in Africa in the mid-1990s (Pretorius et al., 2001). Then, in 2001, it was found in Paraguay and in the west of the state of Paraná, Brazil, spreading, within three years, throughout South America (Rossi, 2003; Yorinori et al., 2005). In 2004, ASR was reported in the continental United States (Schneider et al., 2005). 
The typical symptom of the disease are small, tan-colored lesions formed mainly on the abaxial surface of soybean leaflets. Lesions are frequently associated with leaf chlorosis, and high lesion density leads to premature defoliation and early maturity, resulting in significant yield losses (Hartman et al., 2015). In the absence of control measures, yield losses of up to $90 \%$ have been reported (Bromfield, 1984; Hartman et al., 2015).

The fungus $P$. pachyrhizi is an obligate parasite that produces both uredospores and teliospores (Hartman et al., 2015). So far, only uredospores are known to be important in epidemics. The survival of the fungus throughout the year relies on the continued production of uredospores on a suitable host. Along with soybean, more than 90 other legume species serve as P. pachyrhizi hosts (Rytter et al., 1984; Slaminko et al., 2008). In general, optimal weather conditions for the crop favor the establishment and development of the disease. The fungus infects plants at temperatures ranging from 10 to $27.5^{\circ} \mathrm{C}$ (optimal temperature of $20-23^{\circ} \mathrm{C}$ ) and when the minimum dew period is 6 hours (Melching et al., 1989). Continuous leaf wetness caused by dew or rain also favors the development of the disease, considering that rainfall is an important factor in determining epidemic levels in the field (Del Ponte et al., 2006).

In Brazil, yield losses due to ASR vary among crop seasons (Table 1). In the first years after its report, losses occurred because the farmers were unaware of the existence of the fungus and lacked the fungicides to control it, reaching 4.6 million tons of grain in 2003/2004. In 2004, to manage the disease, the Anti-rust Consortium was established - a task force led by Embrapa, the Brazilian Agricultural Research Corporation, and formed by public and private sectors. The initial goals of the consortium were to standardize the existing information and transfer it to the whole soybean chain, as a way to reduce yield losses. While yield losses decreased, the use of fungicides was intensified. Costs in dealing with ASR were estimated in US\$ 2.2 billion in 2013/2014 (Table 1), and the control was carried out with an average of three fungicide applications per soybean crop season. Besides gathering information on the fungus, the Anti-rust Consortium has also the purpose of identifying occurrences of the disease during the crop seasons, through a network of labs in the main growing regions (Consórcio Antiferrugem, 2015).

The management of ASR has brought changes to the agricultural system in Brazil, with restrictions on planting date, which include a soybean-free period of 60-90 days in the off-season and a sowing limit in some states.

This review article aims to sum up: the main changes in the soybean crop system caused by the introduction of $P$. pachyrhizi in Brazil; the management strategies currently adopted to avoid losses; and the new trends to improve management in the future. This improvement could be achieved by exploring natural genetic resistance in soybean and other legumes, as well as the potential of genetic engineering strategies using genetically modified organisms and RNAi.

\section{Sowing dates and public policies}

Worldwide, soybean production areas where ASR occurs can be divided into two types: where the fungus survives year-round if a suitable host is present, and where seasonal rust epidemics rely on the long-distance dispersal of the inoculum from a source area ( $\mathrm{Li}$ et al., 2010). The environmental conditions in much of Brazil, Paraguay, and Bolivia are conducive to the year-round survival of the pathogen, whereas the occurrence of rust epidemics in Argentina and in the United States soybean belt depends on the dispersal of uredospores produced in areas distant from these regions (Pivonia \& Yang, 2004; Li et al., 2010).

Before $P$. pachyrhizi introduction in Brazil, sowing soybean for seed production was a common practice in the off-season under irrigation (June to September), mainly in the Cerrado (savanna-like vegetation) region. After ASR introduction, these soybean areas provided a green bridge for the fungus to survive during the offseason (Tecnologias de Produção de Soja, 2013). This was observed in the regular crop season, in which rust incidence was recorded during the vegetative stage of soybean sown in nearby areas. In the 2003/2004 crop season, rust was reported 25 days after germination in the municipalities of Sorriso, Campo Novo do Parecis, Campos de Júlio, Sapezal, and Primavera do Leste, in the state of Mato Grosso, and in the municipality of Goiânia, in the state of Goiás, Brazil.

Aiming to reduce the inoculum during the offseason, starting in 2005, the technical recommendation 
Table 1. Estimated grain losses and costs due to Asian soybean rust control in Brazil, since the 2001/2002 crop season ${ }^{(1)}$.

\begin{tabular}{|c|c|c|c|}
\hline Crop season & Grain $\operatorname{loss}^{(2)}$ & Rust $\cos ^{(3)}$ & Observations \\
\hline $2001 / 2002$ & $\begin{array}{l}569.2 \text { thousand tons } \\
\text { (US } \$ 125.5 \text { million) }^{(a)}\end{array}$ & US\$ 177 million & $\begin{array}{l}\text { Unaware of the presence of the fungus in Brazil, the farmers were unprepared } \\
\text { to diagnose and control it. No fungicides registered for soybean rust. } \\
\text { Benzimidazole was involved in } 80 \% \text { of fungicide applications, with no } \\
\text { efficiency on rust control. Economic losses were observed in the states of Rio } \\
\text { Grande do Sul, Paraná, Mato Grosso do Sul, Mato Grosso, and Goiás. }\end{array}$ \\
\hline
\end{tabular}

$2002 / 2003 \quad 3.4$ million tons (US\$ 737.4 million) $)^{(b)}$

$2003 / 2004$

4.6 million tons (US\$ 1.22 billion) $^{(\mathrm{c})}$

$2004 / 2005$

Losses not estimated; only localized occurrences

2.9 million tons

2005/2006 (US\$ 640 million $^{(a)}+$ $10 \%$ taxes)

2.67 million tons 2006/2007 (US\$ 615.7 million) ${ }^{(\mathrm{d})}$

418.5 thousand tons 2007/2008 (US\$ 204.5 million) ${ }^{(\mathrm{e})}$

2008/2009 571.8 thousand tons (US\$ 71.7 million) $)^{(\mathrm{f})}$

$2009 / 2010$

Losses not estimated; only localized occurrences 2010/2011 $\begin{gathered}\text { Losses not estimated } \\ \text { only localized }\end{gathered}$ occurrences 2011/2012 $\begin{gathered}363.5 \text { thousand tons } \\ \text { (US\$ } 191.6 \text { million) }^{(\mathrm{g})}\end{gathered}$
2012/2013 Losses not estimated; alized occurrences
Losses not estimated; only localized occurrences

US\$ 1.16 billion

\section{US $\$ 2.08$ billion}

US\$ 1.215 billion

Control cost: US\$ 1.215 billion

(US\$ 32.6/spray x 2 sprays $-80 \%$ of cultivated area)

US\$ 2.124 billion Control cost: US\$ 1.42 billion

(US\$ $40 /$ spray x 2 sprays $-80 \%$ of cultivated area)

US\$ 2.19 billion Control cost: US\$ 1.58 billion (US\$ 33 /spray x 2.3 sprays $-99 \%$ of cultivated area)

US\$2.38 billion Control cost: US\$ 1.97 billion (US\$ 43/spray x 2.2 sprays)

US\$ 1.74 billion Control cost: US\$ 1.67 billion (US\$ $30 /$ spray x 2.4 sprays)

US\$ 2.09 billion Control cost: US\$ 2.09 billion (US\$33/spray x 2.7 sprays)

US\$ 2.10 billion Control cost: US $\$ 2.10$ billion (US\$ $35 /$ spray x 2.5 sprays)

US\$ 1.73 billion Control cost: US\$ 1.54 billion (US\$ 22/spray x 2.8 sprays)

Control cost: US\$ 1,94 billion (US\$ $25 /$ spray x 2.8 sprays)

Control cost: US\$ 2.2 billion (US\$ 25/spray x 3 sprays)
Rust occurred in $80 \%$ of Brazilian cultivated area, receiving three spray applications, on average. Five commercial fungicides were registered as an emergency. Major losses in the state of Bahia. Rust was reported in all producer states, except in Roraima and Pará, and in the federal district, Distrito Federal.

Soybean rust occurred in $70 \%$ of the cultivated area, receiving 3.5 sprays per hectare on average. Lack of fungicides to spray. Rust reported in all producer states, except in Roraima and Pará, and in Distrito Federal.

Drought in most of the regions; rust did not have significant impact. Mato Grosso was the most affected state. No disease was registered in Distrito Federal, nor in the states of Bahia, Piauí, Roraima, and Pará.

Off-season soybean sowing increased rust incidence in the crop season. Rust was reported in all producer states, except in Piauí, Roraima, and Pará, and in Distrito Federal.

The soybean-free period implemented in the states of Tocantins, Goiás, and Mato Grosso reduced early onset of rust. Growing season with El Niño influence and good rain distribution favored the epidemics. Rust reported in all producer states, except in Roraima and Pará, and in Distrito Federal.

Soybean-free period implemented in the states of Tocantins, Goiás, Mato Grosso, Mato Grosso do Sul, Minas Gerais, São Paulo, and Maranhão. At the end of the growing season, a lower efficiency of DMI fungicides was reported. Rust reported in all producer states, except in Piauí, Pará, and Roraima, and in Distrito Federal.

Soybean-free period also implemented in the state of Paraná. Drought in most of the growing regions. Rust reported in all producer states, except in Pará and Roraima, and in Distrito Federal. Epidemics in the state of Bahia.

The rainy winter was favorable for the survival of the fungus in volunteer soybean plants, and the weather was favorable during the crop season for epidemics. Fungicide sprays avoided losses. Rust reported in all producer states, except in Pará and Roraima.

Dry winter helped to decrease the fungus population. The Anti-Rust Consortium started recommending only the application of a premix of DMI and QoI fungicides due to the lower efficiency of DMIs in all regions. Fungicide sprays avoided losses. Rust reported in all producer states, except in Piauí, Maranhão, Tocantins, Pará, and Roraima, and in Distrito Federal.

La Niña weather condition: drought in the southern region and in the state of Mato Grosso, with lower incidence and severity of soybean rust. Losses in Mato Grosso. Rust reported in all producer states, except in Piauí, Maranhão, Tocantins, and Roraima.

Volunteer soybean plants with rust overwinter in Mato Grosso. El Niño weather condition: irregular rain occurrence. Low disease severity in the South of the country. Rust reported in all producer states, except in Piauí, Tocantins, Pará, and Roraima.

Low disease severity in the South and Southeast regions due to below-average rainfall and high temperature. In the Center-West region, late-sowed soybean had high severity (with rains in February). Lower efficiency of QoI and of a premix of QoI + DMI. Rust reported in all producer states, except in Piauí, Pará, and Roraima.

${ }^{(1)}$ Source: Consórcio Antiferrugem (2015). (2)Calculated considering soybean price: (a)US\$ 220.50 per ton; (b)US\$ 220 per ton; (c)US\$266 per ton; (d)US\$ 230.6 per ton; (e)US\$ 488.72 per ton; ${ }^{\left({ }^{()}\right.}$US $\$ 230.65$ per ton; and ${ }^{\left({ }^{(g)} U S \$ 527.07\right.}$ per ton. ${ }^{(3)}$ Control cost + grain losses. DMI, demethylation inhibitor; and QoI, quinone outside inhibitor. 
was to adopt a soybean-free period of 90 days without soybean under irrigation and without volunteer soybean plants in the fields. However, due to the liberation of Roundup Ready soybean crops (Monsanto Company, Saint Louis, MO, USA) in Brazil in that same year, irrigated soybean was sown in the off-season to multiply seeds, beyond what was recommended. In the off-season of 2005, 16.000 ha of soybean were sown in the municipality of Primavera do Leste, in the state of Mato Grosso.

In the 2005/2006 growing season, rust was reported again in the vegetative stage, in irrigated areas of the municipality of Guaíra, in the state of São Paulo, and of the municipalities of Primavera do Leste and Alto Garças, in the state of Mato Grosso. In Primavera do Leste, rust was observed 18 days after germination, requiring up to seven fungicide applications for its control.
In 2006, the states of Mato Grosso, Goiás, and Tocantins implemented the soybean-free period. In 2007, Ministério da Agricultura, Pecuária e Abastecimento, the Brazilian Ministry of Agriculture, Livestock and Food Supply, implemented the National Program for Asian Soybean Rust Control. According to this program, all states should evaluate the need to implement or not the soybean-free period with a minimum of 60 days in the off-season. In this same year, the program was adopted in the states of São Paulo, Maranhão, Minas Gerais, Bahia, and Paraná, as well as in the federal district, Distrito Federal. In the state of Rio Grande do Sul, in southern Brazil, the state agricultural agency decided that the frost during the off-season was enough to eliminate volunteer soybean. In 2008, the soybean-free period was implemented in the state of Santa Catarina, and, in 2009, in the states of Pará and Rondônia. However, in 2009, Santa Catarina

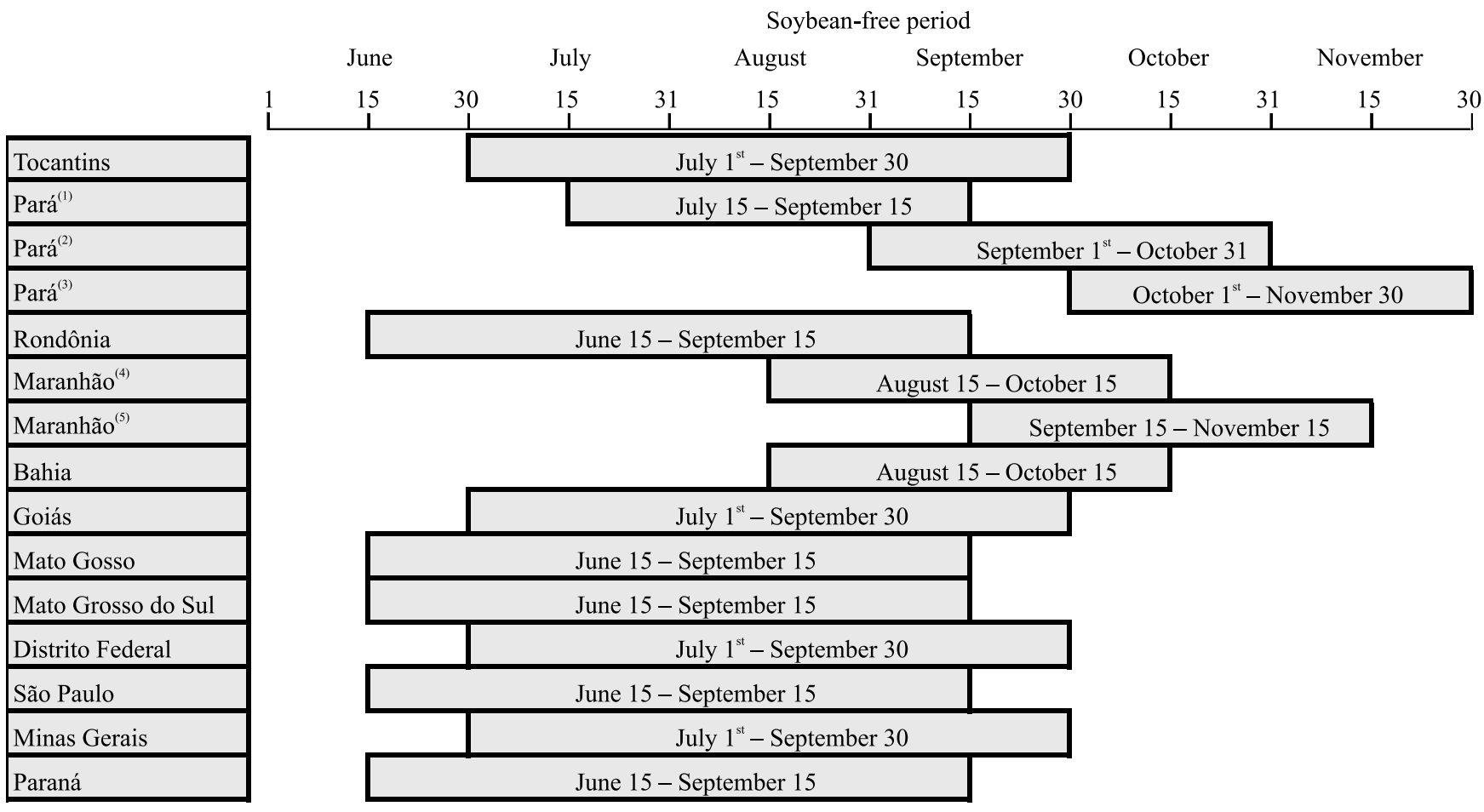

Figure 1. Soybean-free periods in Brazil. ${ }^{(1)}$ Microregion of Conceição do Araguaia, Redenção, Marabá, São Félix do Xingu, Parauapebas, Itaituba (except for the municipalities of Rurópolis and Trairão), and Altamira (districts of Castelo de Sonhos and Cachoeira da Serra). ${ }^{(2)}$ Microregion of Paragominas, Bragantina, Guamá, Tomé-Açu, Salgado, Tucuruí, Castanhal, Arari, Belém, Cametá, Furos de Breves, and Portel. ${ }^{(3)}$ Microregion of Santarém, Almeirim, Óbidos, Itaituba (municipalities of Rurópolis and Trairão), and Altamira (except for the districts of Castelo de Sonhos and Cachoeira da Serra). ${ }^{(4)}$ Microregion of Alto Mearim, Grajaú, Balsas, Imperatriz, and Porto Franco. ${ }^{(5)}$ Microregion of Baixada Maranhense, Caxias, Chapadinha, Codó, Coelho Neto, Gurupi, Itapecuru Mirim, Pindaré, Presidente Dutra, Rosário, Paço do Lumiar, Raposa, São José de Ribamar, and São Luís. 
revoked the normative, claiming similar conditions to those of Rio Grande do Sul.

Currently, 12 states have adopted the soybean-free period, three of 60 days (Pará, Maranhão, and Bahia) and nine of 90 days (Figure 1). The period of 90 days, recommended by the Anti-rust Consortium, included a safety margin in the higher spore-survival period, which was of 55 days in infected leaflets stored in the shade (Patil et al., 1998).

The soybean-free period provided a delay in the first onset of the disease (Figure 2). The restriction period ends in September $15^{\text {th }}$ in the first states, and the onset of ASR has been reported in commercial fields after November.

Despite the 60-90-day soybean-free period, the large sowing window provides a great amount of inoculum for late-sown soybean and an early onset of the disease, which increases the number of fungicide applications and reduces the intervals among them. To reduce the selection pressure for fungicide resistance caused by the large number of fungicide applications on $P$. pachyrhizi since 2014, the states of Goiás and Mato Grosso have also set a sowing date limit until December 31. This measure will also be implemented in 2017 in the state of Paraná (Consórcio Antiferrugem, 2015).

\section{Monitoring the disease}

In 2004, Embrapa Soja, a research unit of Embrapa, located in the state of Paraná, Brazil, released a warning system project called "Sistema de Alerta". This warning system was designed to inform public and private technical assistance about problems detected during the growing season, to guide possible solutions and to capture information about the performance of the crop in the various producing regions. From $2004 / 2005$ to $2006 / 2007$, the warning system hosted the ASR occurrence map, a real-time system used to monitor the distribution of the disease throughout Brazil. Since 2007/2008, the Anti-rust Consortium has also been hosted in the website (Consórcio

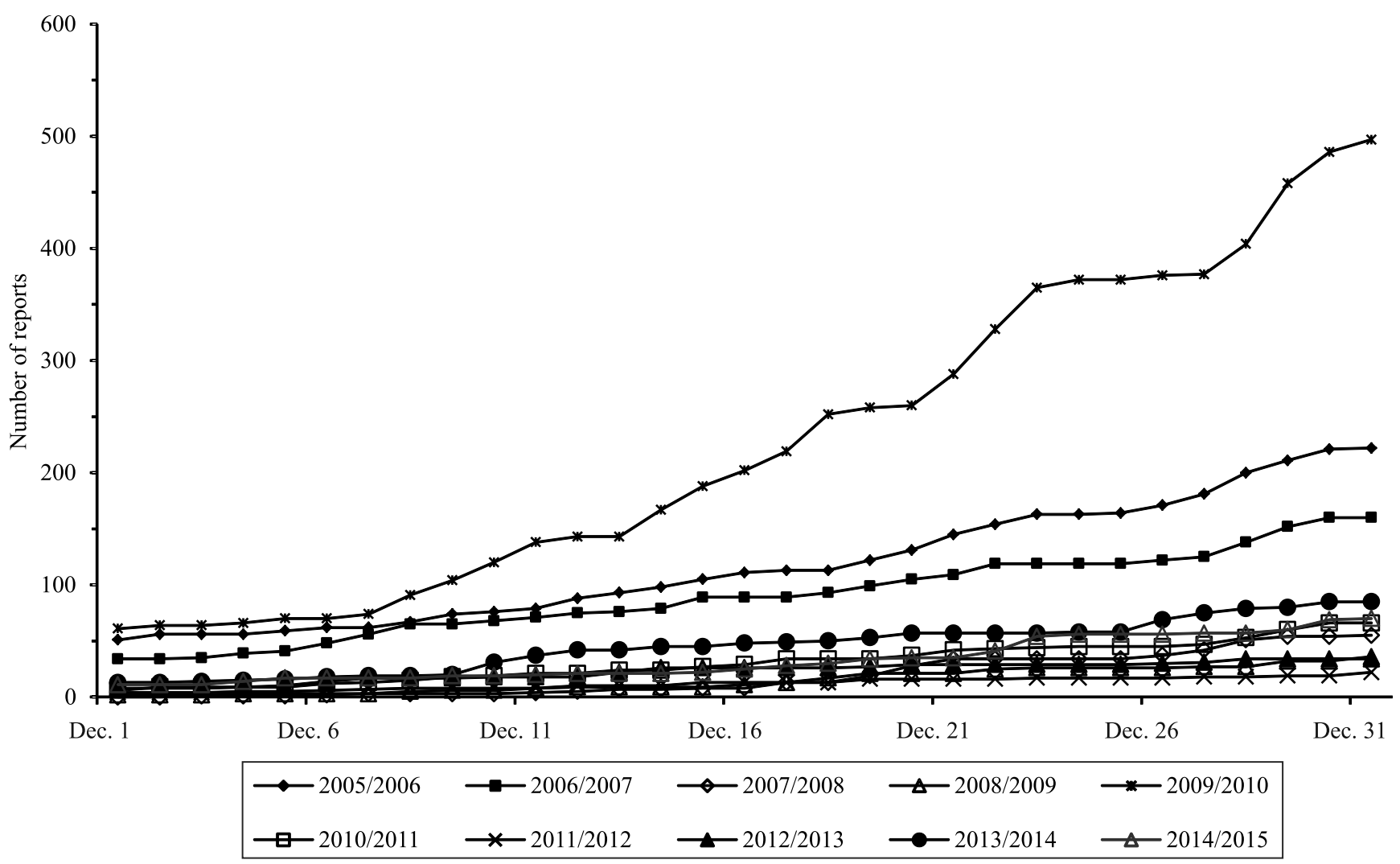

Figure 2. Number of reports of Asian soybean rust in December, from 2005/2006 to 2014/2015 (Consórcio Antiferrugem, 2015). 
Antiferrugem, 2015). Programs to monitor diseases are important for crops with broad geographic distribution or for diseases that can cause rapid and great economic losses, such as potato late blight (Krause et al., 1975), rusts on cereal crops (Verreet et al., 2000), and soybean rust in the United States (Sikora et al., 2014). Public and private labs at universities, farmer cooperatives, Embrapa units, and technical assistance, all inform ASR occurrences through the website.

The official soybean-growing season in Brazil starts on September $16^{\text {th }}$, after the first soybean-free period has ended. After the implementation of soybean restriction in the off-season, ASR tends to start in November, with the exception of years with El Niño events, as observed in 2009/2010 (Figure 2); however, initial occurrences of the disease may vary among growing seasons. Therefore, monitoring efforts are to accurately report first occurrences, to warn growers about the need to start fungicide control. It should be noted that, since 2013, overwintered volunteer soybean plants with ASR have started to be reported on the map, especially in the states that do not adopt the soybean-free period.

\section{Fungicides}

The use of fungicides on soybean was intensified in Brazil after ASR introduction. The first ones labeled for ASR control were those that had already been used for other pathogens on soybean and which showed efficient control of ASR in previous trials. The number of labeled fungicides increased from 5, in 2002, to 117, in 2015 (Brasil, 2015). In the first years, the majority of the labeled fungicides belonged to the demethylation inhibitor (DMI) group and to a premix of DMIs and quinone outside inhibitors (QoIs). Since 2013, commercial mixtures of succinate dehydrogenase inhibitors (SDHIs) and QoI have also been used (Brasil, 2015).

Since their first years of use, these fungicides have differed greatly in their effectiveness in controlling ASR. Therefore, in Brazil, fungicide efficacy has been evaluated annually since 2003/2004 in a nationwide network of standardized, uniform field trials (UFTs). Nowadays, these trials are coordinated by Embrapa Soja; Tagro Tecnologia Agropecuária Ltda. (Londrina, PR, Brazil), a private research company; and Universidade de Rio Verde (Rio Verde, GO, Brazil), a state university. The number of compounds evaluated in UFTs varies each year, but all trials include new compounds under registration process and the most commonly used fungicides. The results from UFTs have provided historical information about differences in fungicide performance over time and among different regions in Brazil.

The results obtained from 2003/2004 to $2006 / 2007$ were reviewed quantitatively using a metanalysis (Scherm et al., 2009). It was observed that, in general, DMI fungicides applied alone performed better than QoIs applied alone, but there was a wide range of efficacy among DMIs: prothioconazole and tebuconazole were the most effective, whereas fluquinconazole and difenoconazole were the least effective. Application of QoIs alone was recommended only in the first growing season, and, since then, should only be used if associated with other fungicides for ASR control in Brazil.

Even though DMIs were more effective than QoIs in earlier trials, their effectiveness has decreased over time. The DMI tebuconazole was as effective as standard mixtures of DMI + QoI until 2006/2007, based on the average percentage of ASR control in UFTs (Figure 3). The DMI compounds were less effective in some regions at the end of the 2007/2008 crop season, mainly in the Cerrado region, reflecting the average of control in UFTs. The first attempts to manage resistance risks, especially for DMIs used alone, were carried out in 2008. In the Cerrado region, the strategy in the 2008/2009 growing season was to avoid using DMIs alone and to use DMI + QoI mixtures to control ASR (Godoy, 2012). Until 2008/2009, tebuconazole was as effective as DMI + QoI mixtures to control ASR in the South of the country, but DMIs were recommended only at the beginning of the growing season and never in sequential application. In 2009/2010, the DMIs controlled the disease less effectively in southern Brazil, and the recommendation to use DMI + QoI mixtures to control ASR was extended to all soybean producing regions of the country (Godoy, 2012).

After 2007/2008, the decrease in efficacy became a general trend for DMI fungicides. The only exception was prothioconazole, which was launched in 2010, although it had been assessed since 2005/2006. Because of the reduced efficacy of DMIs, prothioconazole was launched as a mixture with trifloxystrobin.

The weaker efficacy of DMIs six years after ASR was first detected in Brazil was associated with 
the selection of less sensitive populations of the fungus. Several factors have contributed to fungicide resistance. The first one is the frequent exposure of the pathogen to fungicides. Until 2007, DMIs were widely used in sequential and curative applications to control ASR. The average latent period of $P$. pachyrhizi is about 7-9 days (Marchetti et al., 1976), and the disease tends to start at the bloom stage, around 45-50 days after sowing. From the first fungicide application to the end of the season, 8 to 10 cycles of fungal infection can take place and all are likely to be exposed to the fungicide. Another factor favoring selection pressure is the large soybean sowing window in Brazil, from mid-September to December, and the possibility of double soybean crop seasons in some regions. Therefore, overlapping generations of $P$. pachyrhizi spores are exposed to the fungicide, and the spores are easily spread by wind from one field to another. In fields with late-sown soybean, farmers must reduce the interval between fungicide applications, due to the larger amount of inoculum produced in the earlier-sown soybean. Therefore, the average number of fungicide applications during one soybean cycle increases: two for early-sown soybean, four for late-sown soybean, and six for a second soybean crop. Approximately 10-12 fungicide applications are performed from September to May, taking into account the overlapping of soybean crop seasons and areas.

Monitoring of P. pachyrhizi sensitivity to fungicides in Brazil started in 2005 by Bayer CropScience Brasil (São Paulo, SP, Brazil). For DMIs, the detached leaf method is recommended by the Fungicide Resistance Action Committee (FRAC) (2015). The minutes of the FRAC meeting in 2014 and the recommendations for 2015 are based on monitoring programs carried out by BASF S.A. (Morumbi, SP, Brazil), Bayer Cropscience Brasil, FRAC Brasil (Jaguariúna, SP, Brazil), and Syngenta Brasil (São Paulo, SP, Brazil). A sensitivity baseline has been established in Brazil taking into account the 2005/2006 data. Sensitivity shifts have occurred, but sensitivity has tended to stabilize after the 2010/2011 growing season. In addition, variations in sensitivity have been observed within and among

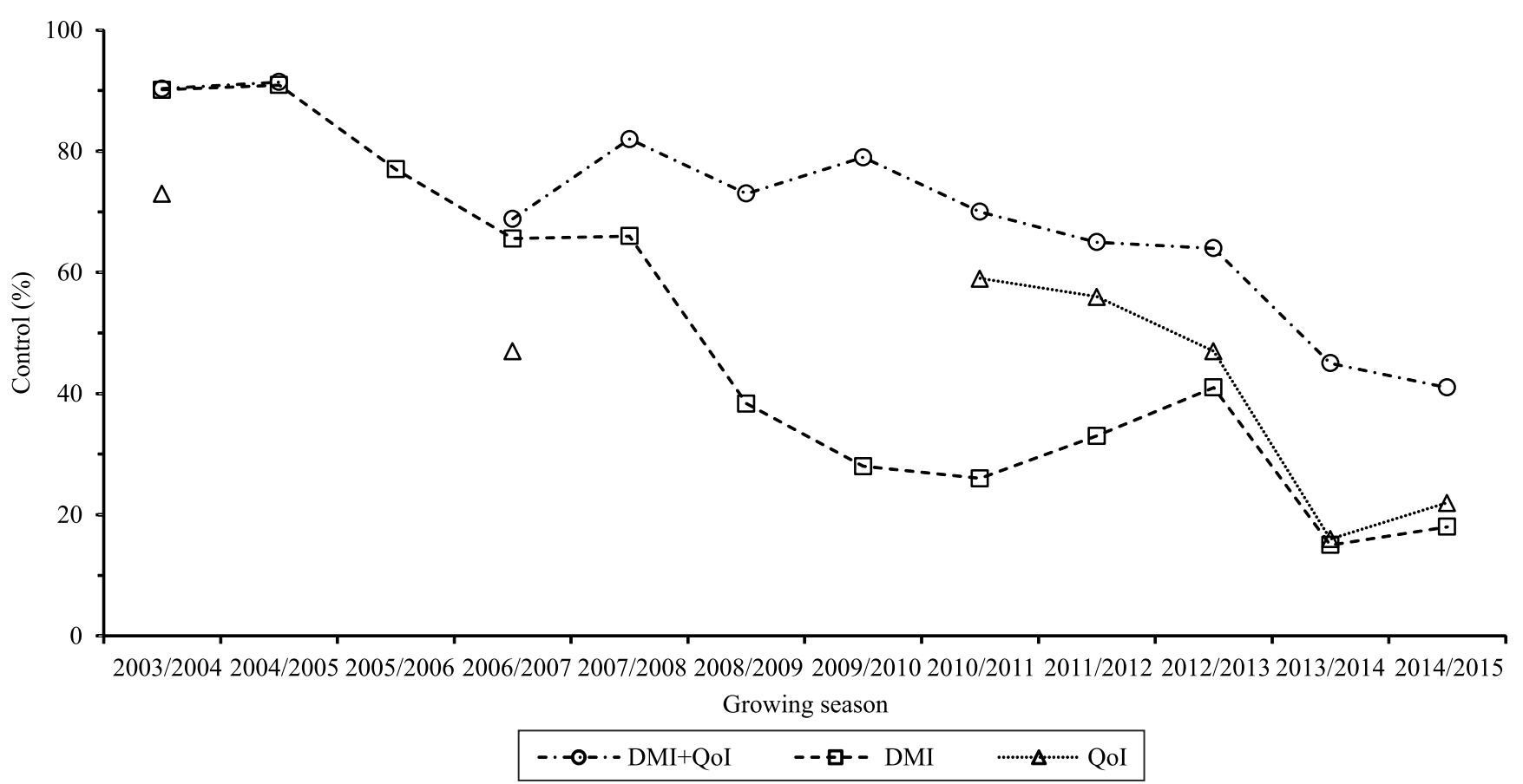

Figure 3. Percentage of Asian soybean rust control in uniform field trials in different soybean-producing regions in Brazil, in the following growing seasons: 2003/2004, 11 trials; 2004/2005, 20 trials; 2005/2006, 15 trials; 2006/2007, 10 trials; 2007/2008, 7 trials; 2008/2009, 23 trials; 2009/2010, 15 trials; 2010/2011, 11 trials; 2012/2013, 21 trials; 2013/2014, 16 trials; and 2014/2015, 21 trials. DMI + QoI, cyproconazole + azoxystrobin; QoI, azoxystrobin; and DMI, tebuconazole. Source: adapted from Godoy (2012) and Godoy et al. (2011, 2012, 2013, 2014, 2015a). 
fungi populations (Schmitz et al., 2014; Xavier et al., 2015).

In several pathogens, the genetic background of resistance to DMIs is known to be associated with one or several point mutations in the CYP51 gene, which encodes the target sterol demethylase. Analysis of the CYP51 gene of P. pachyrhizi strains collected in different regions of Brazil in 2010 revealed that point mutations and efflux transporter overexpression were related to a reduced sensitivity to DMIs. The mutations linked to an increased median effective dose $\left(\mathrm{ED}_{50}\right)$ were F120L, Y131F/H, K142R, I145F, and I475T. Some DMI-adapted isolates showed a constitutive up-regulation of CYP51 of up to 10-fold (Schmitz et al., 2014).

It was expected that the soybean-free period would reduce the quantity of the less-sensitive fungus population, but this was not observed. This result indicates that the less sensitive population of $P$. pachyrhizi was sufficiently fit to survive and propagate over time. Based on the UFT data, the effectiveness of tebuconazole alone reached $18 \%$ in 2015, with three applications (Figure 3).

QoI fungicides were less effective than other fungicides when applied alone in the first UFTs, and this group was not included in subsequent trials until 2006/2007, when all of the fungicides were reevaluated. From 2010 onwards, azoxystrobin applied alone has been included in UFTs to monitor its field performance. When applied alone, azoxystrobin showed similar effectiveness from 2010 to 2013 to that in 2006. In 2013/2014, a reduced effectiveness of QoIs was observed in UFTs, although the sensitivity in the monitoring bioassays has remained in the range reported in previous years (Fungicide Resistance Action Committee, 2015).

Resistance to QoI fungicides is associated with mutations in the cytochrome $b$ gene. At least three amino acid substitutions, at positions 143, 129, and 137 are related to QoI resistance in phytopathogenic fungi (Gisi et al., 2000). At these positions, point mutation causes, respectively: a glycine-to-alanine substitution (G143A); an amino acid change from phenylalanine to leucine (F129L); and arginine replacing glycine (G137R) (Edin \& Torriani, 2012). The mutation at position G143 is the most important, because it makes the mutant strain completely uncontrollable with QoI fungicides (Edin \& Torriani, 2012). Isolates with F129L or G137R show only moderate (partial) resistance.

As reported by Grasso et al. (2006), in P. pachyrhizi and other pathogens, a type I intron immediately follows codon 143. The authors predicted that a nucleotide substitution at codon 143 would prevent intron splicing, leading to a deficient cytochrome $b$, which is lethal. Therefore, the evolution of resistance to QoI fungicides based on G143A is not likely to evolve into pathogens that carry an intron directly after this codon. However, molecular analysis of the $P$. pachyrhizi cytochrome $b$ gene populations from 2013/2014 showed high frequency of F129L mutation in field samples and monouredinial isolates; G143A and G137R, however, were not found (Klosowski et al., 2015). The presence of the F129L mutation in P. pachyrhizi may explain the reduced efficiency observed in the UFT in 2013/2014, but another resistance mechanism can also be involved.

The reduced efficiency of DMI and QoI compromised the commercial premix of DMI + QoI at different levels. Although cross-resistance among compounds in the same group occurs, the mutation affects these compounds in different ways. Among QoIs, the efficacy of mixtures containing the QoI picoxystrobin was least affected, as well as of mixtures containing the DMI prothioconazole (Godoy et al., 2012, 2013, 2014, 2015a).

New broad-spectrum fungicides in the SDHI group have been included in UFTs for ASR control since 2011/2012 (Godoy et al., 2012, 2013, 2014, 2015a). The SDHIs have been tested in mixtures with QoIs or triple mixtures with QoIs and DMIs. In field trials, the benzovindiflupyr + azoxystrobin mixture, launched in Bolivia and Paraguay in 2013 and in Brazil in 2014, was more effective than other DMI + QoI mixtures on the market (Godoy et al., 2013, 2014, 2015a). Another SDHI, fluxapyroxad, was launched in 2012 in a mixture with pyraclostrobin. In UFTs, the fluxapyroxad + pyraclostrobin mixture was grouped with the most effective fungicides, but was less effective than benzovindiflupyr + azoxystrobin (Godoy et al., 2013, 2014, 2015a). In 2013, another SDHI, bixafen, was included in UFTs in a triple mixture with a QoI and a DMI. It should be highlighted that the use of SDHI is increasing rapidly, which may lead to a strong selection pressure for resistance to this group of fungicides. 
Since effective fungicides with a new mode of action are not readily available, old multi-site fungicides, e.g. mancozeb, copper sulfate, chlorothalonil, which have low resistance risk, have been recently re-tested for P. pachyrhizi control in mixtures or tank mixtures to increase control efficiency and reduce the risk of resistance (Godoy et al., 2015b).

\section{Genetic resistance}

Natural resistance is a common alternative explored by plant breeders for disease control and involves deploying naturally resistant sources. For ASR, it can reduce the cost of chemical control, improve efficiency, and reduce selection pressure for resistance to fungicides.

Plant resistance genes to P. pachyrhizi (Rpp) are often governed by specific resistance genes that interact with avirulence genes of the pathogen, leading to a specific gene interaction that culminates in the effector triggered immunity, involving the production of reactive oxygen species and a hypersensitivity response in the infection site (Dodds \& Rathjen, 2010). This interaction involves the development of pathogen races differing in avirulence genes for a certain plant resistance gene.

To date, six major dominant resistance loci (Rpp1-Rpp6) have been identified and mapped on the soybean genome, but none of the genes has been cloned. The Rpp 1, Rpp 4, and Rpp6 genes were mapped to three different regions of chromosome 18 (Hyten et al., 2007; Silva et al., 2008; Li et al., 2012), Rpp2 on chromosome 16 (Silva et al., 2008), Rpp3 on chromosome 6 (Hyten et al., 2009), and Rpp 5 on chromosome 3 (Garcia et al., 2008). The Rpp? (Hyuuga) gene was mapped to the same interval as Rpp3 (Monteros et al., 2007), and a new allele of Rpp 1, designated Rpp 1-b, was mapped in the PI 594583A accession and is also likely present in PI 587880A, PI 587886, and PI 561356 (Chakraborty et al., 2009; Ray et al., 2009; Kim et al., 2012). The recessive allele rpp2 was also mapped in PI 224270 at the same region as Rpp2, whereas three different alleles have been reported for Rpp5, including a dominant allele from PI 200526 and PI 200487, an incompletely dominant allele from PI 471904, and a recessive allele from PI 200456 (Garcia et al., 2008).

Based on the presence or absence of a specific resistance gene, three possible infection phenotypes can be observed during soybean- $P$. pachyhrizi interaction: Tan, RB, and immune. A tan-colored lesion with sporulating uredinia is the susceptible interaction, whereas resistant cultivars generally develop reddish-brown lesions (RB) with little or no sporulation. The immune phenotype is reported in an incompatible interaction without any visible disease symptoms on host leaves (Bromfield, 1984).

To exploit natural variation for resistance, large-scale germplasm screening has been employed along with molecular markers and/or positional cloning to identify resistance genes that confer resistance in a wide germplasm range of crop plants and their wild relatives. So far, over 1,600 soybean accessions have been screened for resistance or tolerance to ASR, but few additional sources have been identified. No soybean line has been found with broad-spectrum resistance to all isolates of $P$. pachyrhizi (Miles et al., 2006, 2008). Furthermore, another technique, the latest next-generation sequencing platforms, has improved the capacity to assess genetic variability at the genomic level in soybean accessions. It revealed important polymorphisms and haplotypes among individuals that responded differently to different isolates of the pathogen, improving the capacity of marker selection based on single polymorphism nucleotides (Kim et al., 2012; Harris et al., 2015; Yu et al., 2015).

Single, dominantly inherited $\mathrm{R}$ gene-mediated resistance against $P$. pachyrhizi has been overcome in the nature due to the high variability of the pathogen (Bromfield, 1984; Hartman et al., 2005; Yorinori et al., 2005).

From 2007 to 2010, a study was carried out to characterize pathogenic variability in $P$. pachyrhizi populations collected from different regions of Brazil, Argentina, and Paraguay. A set of differential germplasm was used to determine the types of reaction of soybean plants, considering the presence or absence of lesions, number of uredinia per lesion, and sporulation level on inoculated plants. The results showed that the fungi populations from South America vary geographically and temporally in pathogenicity, and that Rppl (PI 587880A) and Rpp5 were the most effective against ASR (Akamatsu et al., 2013).

Commercial resistant cultivars harboring resistance genes to $P$. pachyrhizi have been available in Brazil since 2009, such as Inox, generated by Tropical Melhoramento \& Genética (Cambé, PR, Brazil), 
and BRS, by Embrapa (Brasília, DF, Brazil). The most common breeding technique used is genetic introgression, but stacking of two or more genes is also done, aiming at more effective and durable resistance. These cultivars are recommended with fungicide application to reduce $P$. pachyrhizi multiplication; otherwise, this could lead to a selection pressure to overcome the resistance genes.

Screening for resistance to $P$. pachyrhizi has been expanded to close relatives of soybean, such as Glycine max subsp. soja (Siebold \& Zucc.) H.Ohashi. and other perennial Glycine ssp. Moreover, resistance to P. pachyrhizi was identified in accessions of G. argyrea Tindale, G. canescens F.J.Herm., G. clandestina Wendl., G. latifolia (Benth.) C.A.Newell \& Hymowitz, G. microphylla Tindale, and G. tomentella Hayata, but not in accessions of $G$. arenaria Tindale, G. cyrtoloba Tindale, G. curvata Tindale, and G. falcata Benth. (Hartman \& Wang, 1992). Soybean rust resistance derived from $G$. tomentella in amphiploid hybrid lines was also identified (Patzoldt et al., 2007), and its transference to the cultivated soybean, G. max, might be an alternative to developing resistance to ASR.

\section{Biotechnological strategies applied to ASR resistance}

\section{Nonhost resistance}

Resistance conferred by single, dominant resistance genes is specific to a particular pathogen race, which can express the corresponding avirulence gene(s). Since pathogen avirulence genes could be easily mutated or eliminated, protection conferred by resistance genes is not durable. By contrast, nonhost resistance (NHR) could provide broader and more durable resistance. It can be defined as the immunity of all genotypes of a given plant species against all genetic variants of a given pathogen (Lipka et al., 2005) and involves preformed barriers (such as cell walls, antimicrobial compounds, and other secondary metabolites) and general elicitor-induced defense responses. The durability of this type of resistance might be due to the recognition of general or multiple elicitors by the plant surveillance system or due to the presence of several resistance genes that function simultaneously by recognizing their corresponding avirulence genes from a pathogen (Mysore \& Ryu, 2004).
NHR is best described in Arabidopsis, in which at least two different layers of resistance, related to preand post-penetration defense, led to full compatibility between Arabidopsis and nonhost powdery mildew pathogens (Lipka et al., 2005). The first layer is related to the incapability of invasion of non-adapted fungal pathogens, and, at least three penetration mutants, pen 1, pen2, and pen 3, were described in Arabidopsis. Compared with the wild type, pen mutants enable the entry of nonhost powdery mildew pathogens into epidermal cells at a higher frequency (Lipka et al., 2005). The second layer in NHR in Arabidopsis involves the activation of several plant defense responses, many of them similar to those induced during gene-for-gene or host resistance, such as the production of reactive oxygen species, pathogenesis-related proteins, hypersensitivity responses, and salicylic acid-mediated responses (Mysore \& Ryu, 2004; Lipka et al, 2008). Additionally, an Arabidopsis nonhost resistance gene, NHO1, was identified and is required for resistance against Botrytis cinerea and Pseudomonas syringae isolates from bean (Phaseolus vulgaris L.) or tobacco (Nicotiana tabacum L.), for which Arabidopsis is a nonhost. The $\mathrm{NHOl}$ mutation does not compromise resistance to several other nonhost pathogens, including Alternaria brassicicola, Peronospora trifoliorum, or Xanthomonas oryzae pv. oryzae, suggesting that $\mathrm{NHO1}$ is required for resistance only to certain pathogens (Kang et al., 2003).

Alternative sources for the development of broader or long-term resistance to ASR have been focusing on the NHR of Arabidopsis and other legumes. The study of Arabidopsis NHR against P. pachyrhizi revealed important pre- and post-invasion components, showing the involvement of reactive oxygen species production, unusual cell death in epidermal cells, and the activation of components of the jasmonic-acid pathway of a biotrophic pathogen during the initial steps of infection (Loehrer et al., 2008). In Medicago truncatula Gaertn., NHR for P. pachyrhizi was related to the composition of waxes on abaxial leaf surfaces. The increased disease-resistance phenotype of irgl/ palm1 mutant plants might exhibit altered abaxial leaf surface signals that inhibit differentiation of fungal pre-infection structures (Uppalapati et al., 2012). The interspecies transfer of genes involved in post-invasion-induced NHR from Arabidopsis to soybean has been showing the strategy's potential 
of conferring crop resistance to ASR in greenhouse conditions. Soybean transgenic lines, overexpressing independently three Arabidopsis genes, presented rust resistance, as shown by a reduction of over $50 \%$ in the severity and in the accumulation of fungal mRNA (Langenbach et al., 2015).

\section{Silencing of essential pathogenic genes for pathogenicity}

Rust fungi are biotrophic pathogens that are completely dependent on their host plant for growth and propagation. To promote the infection, they establish a specialized structure (haustorium) involved in nutrient acquisition from the host (Hahn \& Mendgen, 1997) and in protein secretion into host tissues. These proteins, termed effectors, can have either an avirulence or virulence function. In order to establish successful infection, the virulence activity of effectors is associated with the manipulation of normal host cell functions or with the suppression of host defense responses by the pathogen. The recognition of the avirulence protein by the cognate plant-resistance protein triggers a defense response characterized by the rapidly induced necrosis of host cells at the site of infection, referred to as a hypersensitivity response, which restricts the colonization by the pathogen (Catanzariti et al., 2006).

Recently, a large number of effector candidate genes in rusts, as well as of genes involved in penetration, nutrient uptake, and biotrophy, have been described. Besides this, with the availability of the genome sequence of many rust pathogens, the prediction of effector candidates using structural and comparative analysis has increased significantly (Duplessis et al., 2011; Hacquard et al., 2011; Saunders et al., 2012; Cantu et al., 2013; Link et al., 2014; Nemri et al., 2014).

This knowledge has been used in the development of transgenic plants able to silence important pathogen genes based on the activation of the plant and/ or pathogen interference RNA (RNAi) machinery. Silencing constructs of pathogen genes would be expected to be processed by the plant RNAi machinery to produce small interfering RNA (siRNA) molecules that are taken up by the pathogen and interact with the RNA-induced silencing complex to target the pathogen mRNA for degradation or inhibition of the translation (Hannon, 2002). Gene silencing and a loss-of-function phenotype can, therefore, give important clues as to the role of pathogen genes in determining pathogen virulence and infectivity. The down regulation of critical virulence and/or essential genes can lead to compromised pathogenicity and infection, and, consequently, increased plant resistance.

Host-induced gene silencing (HIGS) was observed in the interaction of wheat (Triticum aestivum L.) and barley (Hordeum vulgare L.) with the pathogen Blumeria graminis that causes powdery mildew. Both plants produced small RNA molecules that target the avirulence gene, Avr10, of the pathogen, leading to a disease reduction (Nowara et al., 2010). Additionally, the transient silencing of the mitogen-activated protein kinase (PtMAPK1) genes, cyclofilin (PtCYC1) and calcineriun B $(P t C N B)$, in leaf rust, caused by Puccinia triticina, partially suppresses the growth of P. triticina, $P$. graminis, and $P$. striiformes in wheat (Panwar et al., 2013). A similar strategy for the control of phytopathogenic fungi (patent protection WO2015/004174) was used to obtain stable transgenic or transient plants producing small RNA molecules able to silence the gene cytochrome P450 sterol demethylase (CYP51) of plant pathogens, including fungi and oomycetes. This transgene increased the resistance in Arabidopsis and barley plants, besides inhibiting fungal growth in agar plates, with a growth reduction similar to that of the fungicide tebuconazole, which targets the same gene. The RNAi technology was also explored to obtain transgenic soybean plants producing siRNA against the STM1 gene of P. pachyrhizi (patent US 2012/0246758). This gene encodes a sterol methyltransferase, a key enzyme in the biosynthesis of ergosterol, a component of fungal cell membranes. Some transgenic lines presented a reduction in more than $50 \%$ of the infected leaves.

\section{Concluding remarks}

Asian rust, caused by Phakopsora pachyrhizi, is the most challenging soybean (Glycine max) disease in Brazil. In short, the fungus is able to survive all year-round if a host is available; the disease occurs in the majority of producing regions; and favorable conditions for soybean development are also favorable for epidemics. The adaptation of $P$. pachyrhizi to fungicides and its ability to overcome resistance genes show that no single solution will be able to maintain the sustainability of the crop. To avoid yield losses, all 
management strategies must be associated, including public policies for sowing date.

\section{References}

AKAMATSU, H.; YAMANAKA, N.; YAMAOKA, Y.; SOARES, R.M.; MOREL, W.; IVANCOVICH, A.J.G.; BOGADO, A.N.; KATO, M.; YORINORI, J.T.; SUENAGA, K. Pathogenic diversity of soybean rust in Argentina, Brazil, and Paraguay. Journal of General Plant Pathology, v.79, p.28-40, 2013. DOI: 10.1007/ s10327-012-0421-7.

BRASIL. Ministério da Agricultura, Pecuária e Abastecimento. AGROFIT. Disponível em: <http://agrofit.agricultura.gov.br/ agrofit_cons/principal_agrofit_cons $>$. Acesso em: 25 nov. 2015.

BROMFIELD, K.R. Soybean rust. St. Paul: American Phytopathological Society, 1984. 65p. (Monography, 11).

CANTU, D.; SEGOVIA, V.; MACLEAN, D.; BAYLES, R.; CHEN, X.; KAMOUN, S.; DUBCOVSKY, J.; SAUNDERS, D.G.O.; UAUY, C. Genome analyses of the wheat yellow (stripe) rust pathogen Puccinia striiformis f. sp. tritici reveal polymorphic and haustorial expressed secreted proteins as candidate effectors. BMC Genomics, v.14, p.18-24, 2013. DOI: 10.1186/1471-2164-14-270.

CATANZARITI, A.-M.; DODDS, P.N.; LAWRENCE, G.J.; AYLIFFE, M.A.; ELLIS, J.G. Haustorially expressed secreted proteins from flax rust are highly enriched for avirulence elicitors. The Plant Cell, v.18, p.243-256, 2006. DOI: 10.1105/ tpc. 105.035980 .

CHAKRABORTY, N.; CURLEY, J.; FREDERICK, R.D.; HYTEN, D.L.; NELSON, R.L.; HARTMAN, G.L.; DIERS, B.W. Mapping and confirmation of a new allele at Rpp 1 from soybean PI 594538A conferring RB lesion-type resistance to soybean rust. Crop Science, v.49, p.783-790, 2009. DOI: 10.2135/cropsci2008.06.0335.

COMPANHIA NACIONAL DE ABASTECIMENTO. Séries históricas. Disponível em: <http://www.conab.gov.br/conteudos. php?a $=1252 \&>$. Acesso em: 3 nov. 2015.

CONSÓRCIO ANTIFERRUGEM. Ferrugem da soja. Disponível em: <www.consorcioantiferrugem.net>. Acesso em: 21 nov. 2015.

DEL PONTE, E.M.; GODOY, C.V.; LI, X.; YANG, X.B. Predicting severity of Asian soybean rust epidemics with empirical rainfall models. Phytopathology, v.96, p.797-803, 2006. DOI: 10.1094/ PHYTO-96-0797.

DODDS, P.N.; RATHJEN, J.P. Plant immunity: towards an integrated view of plant-pathogen interactions. Nature Reviews Genetics, v.11, p.539-548, 2010. DOI: 10.1038/nrg2812.

DUPLESSIS, S.; CUOMO, C.A.; LIN, Y.-C.; AERTS, A.; TISSERANT, E.; VENEAULT-FOURREY, C.; JOLY, D.L.; HACQUARD, S.; AMSELEM, J.; CANTAREL, B.L.; CHIU, R.; COUTINHO, P.M.; FEAU, N.; FIELD, M.; FREY, P.; GELHAYE, E.; GOLDBERG, J.; GRABHERR, M.G.; KODIRA, C.D.; KOHLER, A.; KÜES, U.; LINDQUIST, E.A.; LUCAS, S.M.; MAGO, R.; MAUCELI, E.; MORIN, E.; MURAT, C.; PANGILINAN, J.L.; PARK, R.; PEARSON, M.; QUESNEVILLE, H.; ROUHIER, N.; SAKTHIKUMAR, S.; SALAMOV, A.A.; SCHMUTZ, J.; SELlES, B.; SHAPIRO, H.; TANGUAY, P.;
TUSKAN, G.A.; HENRISSAT, B.; VAN DE PEER, Y.; ROUZÉ, P.; ELLIS, J.G.; DODDS, P.N.; SCHEIN, J.E.; ZHONG, S.; HAMELIN, R.C.; GRIGORIEV, I.V.; SZABO, L.J.; MARTIN, F. Obligate biotrophy features unraveled by the genomic analysis of rust fungi. Proceedings of the National Academy of Science of the United States of America, v.108, p.1-23, 2011. DOI: 10.1073/ pnas. 1019315108 .

EDIN, E.; TORRIANI, S. The role of intraspecific parallel genetic adaptation to QoIs in Europe. In: THIND, T.S. (Ed.). Fungicide resistance in crop protection: risk and management. Oxfordshire: CABI, 2012. p.78-86. DOI: 10.1079/9781845939052.0078.

FUNGICIDE RESISTANCE ACTION COMMITTEE. FRAC. Available at: $<$ http://www.frac.info/>. Accessed on: 25 Nov. 2015.

GARCIA, A.; CALVO, É.S.; KIIHL, R.A. de S.; HARADA, A.; HIROMOTO, D.M.; VIEIRA, L.G.E. Molecular mapping of soybean rust (Phakopsora pachyrhizi) resistance genes: discovery of a novel locus and alleles. Theoretical and Applied Genetics, v.117, p.545-553, 2008. DOI: 10.1007/s00122-008-0798-z.

GISI, U.; CHIN, K.M.; KNAPOVA, G.; KÜNG FÄRBER, R.; MOHR, U.; PARISI, S.; SIEROTZKI, H.; STEINFELD, U. Recent developments in elucidating models of resistance to phenylamide, DMI and strobilurin fungicides. Crop Protection, v.19, p.863-872, 2000. DOI: 10.1016/S0261-2194(00)00114-9.

GODOY, C.V. Risk and management of fungicide resistance in the Asian soybean rust fungus Phakopsora pachyrhizi. In: THIND, T.S. (Ed.). Fungicide resistance in crop protection: risk and management. London: CABI, 2012. p.87-95. DOI: 10.1079/9781845939052.0087.

GODOY, C.V.; UTIAMADA, C.M.; MEYER, M.C.; CAMPOS, H.D.; FORCELINI, C.A.; PIMENTA, C.B.; CASSETARI NETO, D.; JACCOUD FILHO, D.S.; BORGES, E.P.; ANDRADE JUNIOR, E.R. de; SIQUERI, F.V.; JULIATTI, F.C.; FEKSA, H.R.; GRIGOLLI, J.F.J.; NUNES JUNIOR, J.; CARNEIRO, L.C.; SILVA, L.H.C.P. da; SATO, L.N.; CANTERI, M.G.; MADALOSSO, M.; GOUSSAIN, M.; MARTINS, M.C.; BALARDIN, R.S.; FURLAN, S.H.; MONTECELLI, T.D.N.; CARLIN, V.J.; VENANCIO, W.S. Eficiência de fungicidas para o controle da ferrugem asiática da soja, Phakopsora pachyrhizi, na safra 2014/15: resultados sumarizados dos ensaios cooperativos. Embrapa Soja: Londrina, 2015a. 6p. (Embrapa Soja. Circular técnica, 111)

GODOY, C.V.; UTIAMADA, C.M.; MEYER, M.C.; CAMPOS, H.D.; FORCELINI, C.A.; PIMENTA, C.B.; CASSETARI NETO, D.; JACCOUD FILHO, D.S.; BORGES, E.P.; ANDRADE JUNIOR, E.R. de; SIQUERI, F.V.; JULIATTI, F.C.; NUNES JUNIOR, J.; SILVA, L.H.C.P. da; SATO, L.N.; MADALOSSO, M.; MARTINS, M.C.; BALARDIN, R.S.; FURLAN, S.H.; CARLIN, V.J.; VENANCIO, W.S. Eficiência de fungicidas multissítios e fertilizantes no controle da ferrugem-asiática da soja, Phakopsora pachyrhizi, na safra 2014/15: resultados sumarizados dos ensaios cooperativos. Embrapa Soja: Londrina, 2015b. 7p. (Embrapa Soja. Circular técnica, 113).

GODOY, C.V.; UTIAMADA, C.M.; MEYER, M.C.; CAMPOS, H.D.; PIMENTA, C.B.; CASSETARI NETO, D.; JACCOUD FILHO, D.S.; BORGES, E.P.; ANDRADE JUNIOR, E.R. de; SIQUERI, F.V.; JULIATTI, F.C.; FEKSA, H.R.; GRIGOLLI, 
J.F.J.; NUNES JUNIOR, J.; CARNEIRO, L.C.; SILVA L.H.C.P. da; SATO, L.N.; CANTERI, M.G.; MADALOSSO, M.; ITO, M.F.; MARTINS, M.C.; BALARDIN, R.S.; FURLAN, S.H.; MONTECELLI, T.D.N.; CARLIN, V.J.; BARROS, V.L.N.P. de; VENANCIO, W.S. Eficiência de fungicidas para o controle da ferrugem asiática da soja, Phakopsora pachyrhizi, na safra 2013/14: resultados sumarizados dos ensaios cooperativos. Embrapa Soja: Londrina, 2014. 7p. (Embrapa Soja. Circular técnica, 103).

GODOY, C.V.; UTIAMADA, C.M.; MEYER, M.C.; CAMPOS, H.D.; ROESE, A.D.; FORCELINI, C.A.; PIMENTA, C.B.; JACCOUD FILHO, D.S.; BORGES, E.P.; SIQUERI, F.V.; JULIATTI, F.C.; FEKSA, H.R.; GRIGOLLI, J.F.J.; NUNES JUNIOR, J.; CARNEIRO, L.C.; SILVA L.H.C.P. da; SATO, L.N.; CANTERI, M.G.; MADALOSSO, M.; ITO, M.F.; MARTINS, M.C.; BALARDIN, R.S.; FURLAN, S.H.; MONTECELLI, T.D.N.; CARLIN, V.J.; BARROS, V.L.N.P. de; VENANCIO, W.S. Eficiência de fungicidas para o controle da ferrugem-asiática da soja, Phakopsora pachyrhizi, na safra 2012/13: resultados sumarizados dos ensaios cooperativos. Embrapa Soja: Londrina, 2013. 7p. (Embrapa Soja. Circular técnica, 99).

GODOY, C.V.; UTIAMADA, C.M.; MEYER, M.C.; CAMPOS, H.D.; ROESE, A.D.; FORCELINI, C.A.; PIMENTA, C.B.; JACCOUD FILHO, D.S.; BORGES, E.P.; SIQUERI, F.V.; JULIATTI, F.C.; HENNING, A.A.; FEKSA, H.R.; NUNES JUNIOR, J.; COSTAMILAN, L.M.; CARNEIRO, L.C.; SILVA, L.H.C.P. da; SATO, L.N.; CANTERI, M.G.; MADALOSSO, M.; ITO, M.F.; BARROS, R.; BALARDIN, R.S.; SILVA, S.A.; FURLAN, S.H.; MONTECELLI, T.D.N.; CARLIN, V.J.; BARROS, V.L.P.; VENANCIO, W.S. Eficiência de fungicidas para o controle da ferrugem asiática da soja, Phakopsora pachyrhizi, na safra 2011/12: resultados sumarizados dos ensaios cooperativos. Embrapa Soja: Londrina, 2012. 8p. (Embrapa Soja. Circular técnica, 93).

GODOY, C.V.; UTIMADA, C.M.; SILVA, L.H.C.P. da; SIQUERI, F.V.; HENNING, A.A.; ROESE, A.D.; FORCELINI, C.A.; PIMENTA, C.B.; JACCOUD FILHO, D.S.; RAMOS JUNIOR, E.U.; BORGES, E.P.; PONTE, E.M. del; JULIATTI, F.C.; FEKSA, H.R.; CAMPOS, H.D.; NUNES JUNIOR, J.; SILVA, J.R.C.; COSTAMILAN, L.M.; NAVARINI, L.; CARNEIRO, L.C.; SATO, L.N.; CANTERI, M.G.; MADALOSSO, M.; ITO, M.A.; CUNHA, M.G.; ITO, M.F.; MEYER, M.C.; MELO, R.A. de C.; BALARDIN, R.S.; IGARASHI, S.; SILVA, S.A. da; FURLAN, S.H.; NORA, T.D.; CARLIN, V.J. Eficiência de fungicidas para o controle da ferrugem-asiática da soja, Phakopsora pachyrhizi, na safra 2010/11: resultados sumarizados dos ensaios cooperativos. Londrina: Embrapa Soja, 2011. 8p. (Embrapa Soja. Circular técnica, 87).

GRASSO, V.; PALERMO, S.; SIEROTZKI, H.; GARIBALDI, A.; GISI, U. Cytochrome $b$ gene structure and consequences for resistance to Qo inhibitor fungicides in plant pathogens. Pest Management Science, v.62, p.465-472, 2006. DOI: 10.1002/ ps.1236.

HACQUARD, S.; PETRE, B.; FREY, P.; HECKER, A.; ROUHIER, N.; DUPLESSIS, S. The poplar-poplar rust interaction: insights from genomics and transcriptomics. Journal of Pathogens, article ID 716041, p.1-11, 2011. DOI: 10.4061/2011/716041.
HAHN, M.; MENDGEN, K. Characterization of in planta-induced rust genes isolated from a haustorium-specific cDNA library. Molecular Plant-Microbe Interactions, v.10, p.427-437, 1997. DOI: 10.1094/MPMI.1997.10.4.427.

HANNON, G.J. RNA interference. Nature, v.418, p.244-251, 2002. DOI: $10.1038 / 418244 a$.

HARRIS, D.K.; KENDRICK, M.D.; KING, Z.R.; PEDLEY, K.F.; WALKER, D.R.; CREGAN, P.B.; BUCK, J.W.; PHILLIPS, D.V.; LI, Z.; BOERMA, H.R. Identification of unique genetic sources of soybean rust resistance from the USDA soybean germplasm collection. Crop Science, v.55, p.2161-2176, 2015. DOI: 10.2135/ cropsci2014.09.0671.

HARTMAN, G.L.; MILES, M.R.; FREDERICK, R.D. Breeding for resistance to soybean rust. Plant Disease, v.89, p.664-666, 2005. DOI: 10.1094/PD-89-0664.

HARTMAN, G.L.; SIKORA, E.J.; RUPE, J.C. Rust. In: HARTMAN, G.L.; RUPE, J.C.; SIKORA, E.J.; DOMIER, L.L.; DAVIS, J.A.; STEFFEY, K.L. (Ed.). Compendium of soybean diseases and pests. $5^{\text {th }}$ ed. St. Paul: American Phytopathological Society, 2015. p.56-58.

HARTMAN, G.L.; WANG, T.C. Sources of resistance to soybean rust in perennial Glycine species. Plant Disease, v.76, p.396-399, 1992. DOI: 10.1094/PD-76-0396.

HYTEN, D.L.; HARTMAN, G.L.; NELSON, R.L.; FREDERICK, R.D.; CONCIBIDO, V.C.; NARVEL, J.M.; CREGAN, P.B. Map location of the Rppl locus that confers resistance to soybean rust in soybean. Crop Science, v.47, p.837-840, 2007. DOI: 10.2135/ cropsci2006.07.0484.

HYTEN, D.L.; SMITH, J.R.; FREDERICK, R.D; TUKER, M.L.; SONG, Q.; CREGAN, P.B. Bulked segregant analysis using the GoldenGate assay to locate the Rpp3 locus that confers resistance to soybean rust in soybean. Crop Science, v.49, p.265-271, 2009. DOI: $10.2135 /$ cropsci2008.08.0511.

KANG, L.; LI, J.; ZHAO, T.; XIAO, F.; TANG, X.; THILMONY, R.; HE, S.Y.; ZHOU, J.-M. Interplay of the Arabidopsis nonhost resistance gene $\mathrm{NHO} 1$ with bacterial virulence. Proceedings of the National Academy of Sciences of the United States of America, v.100, p.3519-3524, 2003. DOI: 10.107/pnas.0637377100.

KIM, K.-S.; UNFRIED, J.R.; HYTEN, D.L.; FREDERICK, R.D.; HARTMAN, G.L.; NELSON, R.N.; SONG, Q.; DIERS, B.W. Molecular mapping of soybean rust resistance in soybean accession PI 561356 and SNP haplotype analysis of the Rpp1 region in diverse germplasm. Theoretical and Applied Genetics, v.125, p.1339-1352, 2012. DOI: 10.1007/s00122-012-1932-5.

KLOSOWSKI, A.C.; MAY DE MIO, L.L.; MIESSNER, S.; RODRIGUES, R.; STAMMLER, G. Detection of the F129L mutation in the cytochrome $b$ gene in Phakopsora pachyrhizi. Pest Management Science, 2015. DOI: 10.1002/ps.4099.

KRAUSE, R.A.; MASSIE, L.B.; HYRE, R.A. Blitecast: a computerized forecast of potato late blight. Plant Disease Reporter, v.59, p.95-98, 1975.

LANGENBACH, C.; SCHULTHEISS, H.; ROSENDAHL, M.; TRESCH, N.; CONRATH, U.; GOELLNER, K. Interspecies gene transfer provides soybean resistance to a fungal pathogen. Plant 
Biotechnology Journal, v.14, p.699-708, 2015. DOI: 10.1111/ pbi. 12418 .

LI, S.; SMITH, J.R.; RAY, J.D.; FREDERICK, R.D. Identification of a new soybean rust resistance gene in PI 567102B. Theoretical and Applied Genetics, v.125, p.133-142, 2012. DOI: 10.1007/ s00122-012-1821-y.

LI, X.; ESKER, P.D.; PAN, Z.; DIAS, A.P.; XUE, L.; YANG, X.B. The uniqueness of the soybean rust pathosystem: an improved understanding of the risk in different regions of the word. Plant Disease, v.94, p.796-806, 2010. DOI: 10.1094/PDIS-94-7-0796.

LINK, T.I.; LANG, P.; SCHEFFLER, B.E.; DUKE, M.V.; GRAHAM, M.A.; COOPER, B.; TUCKER, M.L.; MORTEL, M. van de; VOEGELE, R.T.; MENDGEN, K.; BAUM, T.J.; WHITHAM, S.A. The haustorial transcriptomes of Uromyces appendiculatus and Phakopsora pachyrhizi and their candidate effector families. Molecular Plant Pathology, v.15, p.379-393, 2014. DOI: $10.1111 / \mathrm{mpp} .12099$.

LIPKA, U.; FUCHS, R.; LIPKA, V. Arabidopsis non-host resistance to powdery mildews. Current Opinion in Plant Biology, v.11, p.404-411, 2008. DOI: 10.1016/j.pbi.2008.04.004.

LIPKA， V.; DITTGEN， J.; BEDNAREK， P.; BHAT， R.; WIERMER, M.; STEIN, M.; LANDTAG, J.; BRANDT, W.; ROSAHL, S.; SCHEEL, D.; LLORENTE, F.; MOLINA, A.; PARKER, J.; SOMERVILLE, S.; SCHULZE-LEFERT, P. Preand postinvasion defenses both contribute to nonhost resistance in Arabidopsis. Science, v.310, p.1180-1183, 2005. DOI: 10.1126/ science.1119409.

LOEHRER, M.; LANGENBACH, C.; GOELLNER, K.; CONRATH, U.; SCHAFFRATH, U. Characterization of nonhost resistance of Arabidopsis to the Asian soybean rust. Molecular Plant-Microbe Interactions, v.11, p.1421-1430, 2008. DOI: 10.1094/MPMI-21-11-1421.

MARCHETTI, M.A.; MELCHING, J.S.; BROMFIELD, K.R. The effects of temperature and dew period on germination and infection by uredospores of Phakopsora pachyrhizi. Phytopathology, v.66, p.461-463, 1976. DOI: 10.1094/Phyto-66-461.

MELCHING, J.S.; DOWLER, W.M.; KOOGLE, D.L.; ROYER, M.H. Effects of duration, frequency, and temperature of leaf wetness periods on soybean rust. Plant Disease, v.73, p.117-122, 1989. DOI: 10.1094/PD-73-0117.

MILES, M.R.; FREDERICK, R.D.; HARTMAN, G.L. Evaluation of soybean germplasm for resistance to Phakopsora pachyrhizi. Plant Health Progress, online, 2006. DOI: 10.1094/ PHP-2006-0104-01-RS.

MILES, M.R.; MOREL, W.; RAY, J.D.; SMITH, J.R.; FREDERICK, R.D.; HARTMAN, G.L. Adult plant evaluation of soybean accessions for resistance to Phakopsora pachyrhizi in the field and greenhouse in Paraguay. Plant Disease, v.92, p.96-105, 2008. DOI: 10.1094/PDIS-92-1-0096.

MONTEROS, M.; MISSAOUI, A.M.; PHILLIPS, D.V.; WALKER, D.R.; BOERMA, H.R. Mapping and confirmation of the 'Hyuuga' red-brown lesion resistance gene for Asian soybean rust. Crop Science, v.47, p.829-836, 2007. DOI: 10.2135/cropsci06.07.0462.
MYSORE, K.S.; RYU, C.-M. Nonhost resistance: how much do we know? Trends in Plant Science, v.9, p.97-104, 2004. DOI: 10.1016/j.tplants.2003.12.005.

NEMRI, A.; SAUNDERS, D.G.O.; ANDERSON, C.; UPADHYAYA, N.M.; WIN, J.; LAWRENCE, G.J.; JONES, D.A.; KAMOUN, S.; ELLIS, J.G.; DODDS, P.N. The genome sequence and effector complement of the flax rust pathogen Melampsora lini. Frontiers in Plant Science, v.98, p.1-14, 2014. DOI: 10.3389/ fpls.2014.00098.

NOWARA, D.; GAY, A.; LACOMME, C.; SHAW, J.; RIDOUT, C.; DOUCHKOV, D.; HENSEL, G.; KUMLEHN, J.; SCHWEIZER, P. HIGS: host-induced gene silencing in the obligate biotrophic fungal pathogen Blumeria graminis. Plant Cell, v.22, p.3130-3141, 2010. DOI: $10.1105 /$ tpc. 110.077040 .

PANWAR, V.; McCALLUM, B.; BAKKEREN, G. Host-induced gene silencing of wheat leaf rust fungus Puccinia triticina pathogenicity genes mediated by the Barley stripe mosaic virus. Plant Molecular Biology, v.81, p.595-608, 2013. DOI: 10.1007/ s11103-013-0022-7.

PATIL, V.S.; WUIKE, R.V.; CHIRAME, B.B.; THAKARE, C.S. Viability and survival of uredospores of Phakopsora pachyrhizi Syd in plant debris under different storage conditions. Journal of Soils and Crops, v.8, p.16-19, 1998.

PATZOLDT, M.E.; TYAGI, R.K.; HYMOWITZ, T.; MILES, M.R.; HARTMAN, G.L.; FREDERICK, R.D. Soybean rust resistance derived from Glycine tomentella in Amphiploid hybrid lines. Crop Science, v.47, p.158-161, 2007. DOI: 10.2135/ cropsci2006.05.0328.

PIVONIA, S.; YANG, X.B. Assessment of the potential year-round establishment of soybean rust throughout the world. Plant Disease, v.88, p.523-529, 2004. DOI: 10.1094/PDIS.2004.88.5.523.

PRETORIUS, Z.A.; KLOPPERS, F.J.; FREDERICK, R.D. First report of soybean rust in South Africa. Plant Disease, v.85, p.1288, 2001. DOI: 10.1094/PDIS.2001.85.12.1288C.

RAY, J.D.; MOREL, W.; SMITH, J.R.; FREDERICK, R.D.; MILLES, M.R. Genetics and mapping of adult plant rust resistance in soybean PI 587886 and PI 587880A. Theoretical and Applied Genetics, v.119, p.271-280, 2009. DOI: 10.1007/ s00122-009-1036-Z.

ROSSI, R.L. First report of Phakopsora pachyrhizi, the causal organism of soybean rust in the province of Misiones, Argentina. Plant Disease, v.87, p.102, 2003. DOI: 10.1094/ PDIS.2003.87.1.102A.

RYTTER, J.L.; DOWLER, W.M.; BROMFIELD, K.R. Additional alternative hosts of Phakopsora pachyrhizi, causal agent of soybean rust. Plant Disease, v.68, p.818-819, 1984. DOI: 10.1094/ PD-68-818.

SAUNDERS, D.G.O.; WIN, J.; CANO, L.M.; SZABO, L.J.; KAMOUN, S.; RAFFAELE, S. Using hierarchical clustering of secreted protein families to classify and rank candidate effectors of rust fungi. PLoS One, v.7, p.e29847, 2012. DOI: 10.1371/journal. pone.0029847.

SCHERM, H.; CHRISTIANO, R.S.C.; ESKER, P.D.; DEL PONTE, E.M.; GODOY, C.V. Quantitative review of fungicide efficacy 
trials for managing soybean rust in Brazil. Crop Protection, v.28, p.774-782, 2009. DOI: 10.1016/j.cropro.2009.05.006.

SCHMITZ, H.K.; MEDEIROS, C.-A.; CRAIG, I.R.; STAMMLER, G. Sensitivity of Phakopsora pachyrhizi towards quinone-outside-inhibitors and demethylation-inhibitors, and corresponding resistance mechanisms. Pest Management Science, v.70, p.378-388, 2014. DOI: 10.1002/ps.3562.

SCHNEIDER, R.W.; HOLIER, C.A.; WHITAM, H.K; PALM, M.E.; McKEMY, J.M.; HERNÁNDEZ, J.R.; LEVY, L.; DEVRIES-PATERSON, R. First report of soybean rust caused by Phakopsora pachyrhizi in the continental United States. Plant Disease, v.89, p.774, 2005. DOI: 10.1094/PD-89-0774A.

SIKORA, E.J.; ALLEN, T.W.; WISE, K.A.; BERGSTROM, G.; BRADLEY, C.A.; BOND, J.; BROWN-RYTLEWSKI, D.; CHILVERS, M.; DAMICONE, J.; DEWOLF, E.; DORRANCE, A.; DUFAULT, N.; ESKER, P.; FASKE, T.R.; GIESLER, L.; GOLDBERG, N.; GOLOD, J.; GÓMEZ, I.R.G.; GRAU, C.; GRYBAUSKAS, A.; FRANC, G.; HAMMERSCHMIDT, R.; HARTMAN, G.L.; HENN, R.A.; HERSHMAN, D.; HOLLIER, C.; ISAKEIT, T.; ISARD, S.; JACOBSEN, B.; JARDINE, D.; KEMERAIT, R.; KOENNING, S.; LANGHAM, M.; MALVICK, D.; MARKELL, S.; MAROIS, J.J.; MONFORT, S.; MUELLER, D.; MUELlER, J.; MULROONEY, R.; NEWMAN, M.; OSBORNE, L.; PADGETT, G.B.; RUDEN, B.E.; RUPE, J.; SCHNEIDER, R.; SCHWARTZ, H.; SHANER, G.; SINGH, S.; STROMBERG, E.; SWEETS, L.; TENUTA, A.; VAICIUNAS, S.; YANG, X.B.; YOUNG-KELLY, H.; ZIDEK, J. A coordinated effort to manage soybean rust in North America: a success story in soybean disease monitoring. Plant Disease, v.98, p.864-875, 2014. DOI: 10.1094/PDIS-02-14-0121-FE.

SILVA, D.C.G.; YAMANAKA, N.; BROGIN, R.L.; ARIAS, C.A.A.; NEPOMUCENO, A.L.; DI MAURO, A.O.; PEREIRA, S.S.; NOGUEIRA, L.M.; PASSIANOTTO, A.L.L.; ABDELNOOR, R.V. Molecular mapping of two loci that confer resistance to Asian rust in soybean. Theoretical Applied Genetics, v.117, p.57-63, 2008. DOI: $10.1007 / \mathrm{s} 00122-008-0752-0$.
SLAMINKO, T.L.; MILES, M.R.; FREDERICK, R.D.; BONDE, M.R.; HARTMAN, G.L. New legume hosts of Phakopsora pachyrhizi based on greenhouse evaluations. Plant Disease, v.92, p.767-771, 2008. DOI: 10.1094/PDIS-92-5-0767.

TECNOLOGIAS de produção de soja - Região Central do Brasil 2014. Londrina: Embrapa Soja, 2013. 265p. (Embrapa Soja. Sistemas de produção, 16).

UPPALAPATI, S.R.; ISHIGA, Y.; DORAISWAMY, V.; BEDAIR, M.; MITTAL, S.; CHEN, J.; NAKASHIMA, J.; TANG, Y.; TADEGE, M.; RATET, P.; CHEN, R.; SCHULTHEISS, H.; MYSORE, K.S. Loss of abaxial leaf epicuticular wax in Medicago truncatula irg1/palm1 mutants results in reduced spore differentiation of Anthracnose and nonhost rust pathogens. The Plant Cell, v.24, p.353-370, 2012. DOI: 10.1105/tpc.111.093104.

VERREET, J.A.; KLINK, H.; HOFFMANN, G.M. Regional monitoring for disease prediction and optimization of plant protection measures: the IPM wheat model. Plant Disease, v.84, p.816-826, 2000. DOI: 10.1094/PDIS.2000.84.8.816.

XAVIER, S.A.; KOGA, L.K.; BARROS, D.C.M.; CANTERI, M.G.; LOPES, I. de O.N.; GODOY, C.V. Variação da sensibilidade de populações de Phakopsora pachyrhizi a fungicidas inibidores da desmetilação no Brasil. Summa Phytopathologica, v.41, p.191-196, 2015. DOI: 10.1590/0100-5405/2068.

YORINORI, J.T.; PAIVA, W.M.; FREDERICK, R.D.; COSTAMILAN, L.M.; BERTAGNOLLI, P.F.; HARTMAN, G.E.; GODOY, C.V.; NUNES JUNIOR, J. Epidemics of soybean rust (Phakopsora pachyrhizi) in Brazil and Paraguay from 2001 to 2003. Plant Disease, v.89, p.675-677, 2005. DOI: 10.1094/ PD-89-0675.

YU, N.; KIM, M.; KING, Z.R.; HARRIS, D.K.; BUCK, J.W.; LI, Z.; DIERS, B.W. Fine mapping of the Asian soybean rust resistance gene Rpp2 from soybean PI 230970. Theoretical and Applied Genetics, v.128, p.387-396, 2015. DOI: 10.1007/ s00122-014-2438-0.

Received on December 4, 2015 and accepted on March 8, 2016 